\title{
ENSAYO
}

\section{EL MODELO DE CRECIMIENTO ECONÓMICO SOLOW-SWAN APLICADO A LA CONTAMINACIÓN Y SU RECICLAJE}

\author{
THE SOLOW-SWAN MODEL OF ECONOMIC GROWTH APPLIED TO POLLUTION \\ AND ITS RECYCLING
}

\author{
Darío Ibarra Zavala'
}

\section{RESUMEN}

El presente trabajo combina el modelo de crecimiento económico de Solow-Swan con la generación y absorción de la contaminación. A partir de la siguiente premisa: la producción depende no solo del trabajo y del capital, sino también de la materia prima disponible en la economía. La incorporación de la materia prima al modelo permite que este sea más real mientras se conserven los supuestos típicos. Por otra parte, la contaminación surge como residuo de los procesos productivos, y se reduce debido a la capacidad de la naturaleza para absorber los contaminantes del medio ambiente. Al considerar el reciclaje de la contaminación en el modelo tradicional de crecimiento económico Solow-Swan, el impacto a largo plazo se refleja en la obtención de un mayor nivel de capital, como resultado de un incremento en la materia prima disponible y de un menor grado de contaminación a causa de la reutilización de los desperdicios generados en el proceso productivo. Esto ocurre porque, aun si se mantiene la tasa de ahorro en la economía constante, el reciclaje se traduce en un desplazamiento de la función de producción, el cual tiene el impacto equivalente a un cambio tecnológico. Con ello, el capital per cápita aumenta en la fase estacionaria, y el nivel de contaminación disminuye en virtud de que el reciclaje ayuda a que la naturaleza la absorba.

Palabras clave: Capital natual, contaminación, crecimiento económico, equilibrio de largo plazo, modelo Solow-Swan, reciclaie.

\section{ABSTRACT}

The present work combines the Solow-Swan model of economic growth with the generation and absorption of pollution. Our starting point is the assumption that production relies not only on labor and capital, but also on the raw materials available in the economy. The incorporation of the raw materials renders the model more real while maintaining typical assumptions. On the other hand, pollution is a by-product of production processes and its reduction is a consequence of nature's ability to absorb pollutants from the environment. Upon considering the recycling of the contamination in the traditional model of economic growth Solow-Swan, the long-term impact is reflected in the obtainment of a higher level of capital, as a result of the increased availability of raw materials and of the reduction of pollution on account of the recycling of the wastes generated in the production process. This occurs because, even if the savings rate in the economy remains steady, the recycling causes an upward shift in the production function whose impact is similar to that of technological change. As a result of this the capital per cápita increases in the stationary phase, and the level of pollution diminishes because recycling helps nature absorb it.

Key words: Natural capital, pollution, economic growth, long-range equilibrium Solow-Swan model, recycling.

Fecha de recepción: 18 de enero de 2011 .

Fecha de aceptación: 30 de julio de 2012.

'Unidad Académica Profesional Nezahualcóyotl, UAEM y Laboratorio de Análisis Económico y Social, A. C. Correo-e: darioibarra@yahoo.com 


\section{INTRODUCCIÓN}

El modelo de crecimiento económico de Harrod (1939) y Domar (1946) fue pionero en incorporar la acumulación del capital y el crecimiento económico en el largo plazo, y dio origen al desarrollo de otros con más flexibilidad e información en su análisis, como el Solow-Swan (Solow, 1979), el de Ramsey (1928), y otro cuyo principal marco teórico es el de "generaciones traslapadas" (OLG por su nombre en inglés, Overlaping Generations) atribuido a Diamond (1965). La mayoría de estos sugieren la existencia de dos factores productivos: trabajo y capital; a partir de los cuales se conforma un proceso de optimización intertemporal por parte de los consumidores; por ejemplo, el de Ramsey y el OLG, o bien el ahorro puede estar dado exógenamente, como en el caso de Solow-Swan, de modo que no existe dicho proceso.

El análisis de los modelos se centra en el nivel de capital y consumo de largo plazo, y en su estabilidad e implicaciones, en términos de política económica; ejemplo de ello son los de Blanchard y Fischer (1989), Barro y Sala-i-Martin (1995) y Sala-i-Martin (2000).

Un enfoque olvidado en la literatura sobre crecimiento económico es el de los recursos naturales, cuyo análisis se basa en su explotación y en la sustentabilidad de la economía, bajo la premisa de la existencia de capital natural suficiente para producir. Con todo, hay dos elementos que no han recibido suficiente atención: la presencia de la contaminación y el papel que el reciclaje podría tener en el abatimiento de la misma y en el crecimiento económico. Esto se observa en textos relevantes de la teoría del crecimiento económico de Blanchar y Fischer (1989), Barro y Sal-i-Martin (1995), Sala-i-Martin (2000) y, más recientemente, De La Croix y Michel (2002).

El modelo de Solow-Swan plantea que el crecimiento económico no solo es función del trabajo y el capital, sino también de la materia prima que será transformada por medio del proceso productivo hasta obtener el bien final, el cual puede ser consumido o invertido. Se reconoce que la contaminación se genera en paralelo a la producción o que esta origina residuos; es decir, se produce contaminación después de utilizar los bienes y servicios, en consecuencia, el modelo asume su preexistencia.

La dinámica del crecimiento económico y la contaminación produce un equilibrio estable en el largo plazo. Cuando en términos económicos se hace algún esfuerzo por reciclar, se obtienen dos efectos: 1) se reduce la contaminación, y 2) existe un volumen superior de materia prima, lo que en el largo plazo permite un mayor crecimiento económico. Por ende, el reciclaje tiene un doble efecto positivo en el largo plazo: una reducción de la contaminación y un mayor producto.

La presente contribución se divide en tres secciones: la primera incluye los modelos de crecimiento económico ecológicos; y en la segunda se describen las características del modelo de Solow-Swan, el cual sirve de referencia para la tercera parte, donde se incorpora la materia prima en estado virgen, la materia prima reciclada, así como

\section{INTRODUCTION}

The economic growth model of Harrod (1939) and Domar (1946) was pioneer in incorporating the accumulation of capital and long-term economic growth and prompted the development of other, more flexible models covering a larger amount of information in their analyses, such as those of Solow-Swan (Solow, 1979), Ramsey (1928), as well as one ascribed to Diamond (1965), primarily based on a theoretical framework of "overlapping generations" (OLG). Most of these models suggest the existence of two production factors -labor and capital-that give rise to a process of intertemporal optimization by the consumers, for example, Ramsey's and the OLG models; or else, the savings may be exogenously given, as in the Solow-Swan model, in which case this process does not occur.

The analysis of these models focuses on the level of capital and long-term consumption, and on their stability and implications in terms of economic politics; a few examples of such models are those of Blanchard and Fischer (1989), Barro and Sala-i-Martin (1995), and Sala-i-Martin (2000).

An approach often neglected in the literature on economic growth is that related to the natural resources, which bases its analysis on their exploitation and on the sustainability of the economy, under the assumption that there is sufficient natural capital for production to occur. All in all, there are two elements that have not received sufficient attention: the presence of pollution and the role that recycling may play in its abatement and in economic growth. This may be observed in prominent texts on the theory of the economic growth by Blanchard and Fischer (1989), Barro and Sala-i-Martin (1995), Sala-i-Martin (2000), and, more recently, De La Croix and Michel (2002).

According to the Solow-Swan model, economic growth is function not only of labor and capital but also of the raw materials that will eventually be transformed, through the production process, into the finished product, which can then be consumed or invested. It is an acknowledged fact that pollution is generated in parallel to production or that production causes waste; that is to say, pollution is a consequence of the use of goods and services, and, consequently, the model assumes its preexistence.

The dynamics of economic growth and pollution produce a stable long-term equilibrium. In terms of the economy, any effort to recycle produces two effects: 1) it reduces pollution, and 2) it increases the volume of raw materials, which in the long term allows further economic growth. Thus, recycling has a two-fold positive effect in the long term: reduced pollution and a larger output.

The present contribution is divided into three sections: the first includes green economic growth models; the second describes the characteristics of the Solow-Swan model, which in turn serves as reference for the third part, where both virgin and recycled raw materials and the dynamics of pollution are incorporated. The 
la dinámica de la contaminación. Se determina que bajo condiciones especificas el equilibrio en el largo plazo se mantiene estable.

\section{Modelos de crecimiento económico ecológicos}

La mayoría de los modelos de crecimiento económico asumen que los recursos naturales convertidos en materia prima son abundantes y no se agotan. Autores como Sala-i-Martin (2000) hacen su análisis con tres tipos de modelos: tasas de ahorro e inversión constantes; de optimización dinámica; y con crecimiento endógeno, mas no refieren el tema de los recursos naturales. Barro y Sala-i-Martin (1995) incorporan ahorro e inversión constantes, optimización intertemporal, crecimiento endógeno, economías abiertas y cerradas. Asimismo, su aportación es la inclusión de capital humano; sin embargo, una vez más dejan de lado los recursos naturales y el medio ambiente.

La revista española Cuadernos Económicos de ICE dedica el número 58 (1994) a la teoría del aecimiento económico; en ella se describen los modelos de crecimiento endógeno y se aborda el tema de la convergencia económica, el papel de los mercados financieros en el crecimiento de la economía, la importancia del sector público, el análisis de la población y el equilibrio político-económico, y el crecimiento económico. En estos trabajos persiste la ausencia de la incorporación de los recursos naturales y la contaminación.

Foley y Michl (1999) utilizan el enfoque clásico, es decir, parten de las premisas de Smith (2003) y Ricardo (1987)), y elaboran modelos cuyos resultados no difieren significativamente de los propuestos por Solow (1956) y Ramsey (1928). En particular, su modelo Ricardiano plantea el tema de la tierra como un factor productivo escaso, lo cual sirve como preámbulo al caso más general de crecimiento económico con recursos agotables. Y propone que conforme se agoten los recursos su precio se incrementará hasta hacer rentable el uso de otras tecnologías. En todo caso, Foley y Michl abordan temas que tradicionalmente no se estudian en la literatura del crecimiento económico.

Solow (1986) critica los modelos de crecimiento económico por no tomar en cuenta los recursos naturales; y considera a los modelos de generaciones traslapadas como la mejor opción para tratarlos, además establece que las utilidades de las generaciones futuras deben ser, al menos, iguales a las de la generación actual; y propone que el capital natural, como mínimo, se mantenga constante. Jouvet et al. (2000) coinciden con dicho autor en términos de modelar a través de generaciones traslapadas y sugieren que existe el altruismo intergeneracional, que se manifiesta cuando la contaminación alcanza niveles críticos. Señalan que brindar poca atención a las generaciones futuras implicaría un mayor consumo actual en detrimento del capital natural del porvenir. long-term equilibrium is determined to remain stable under specific conditions.

\section{Green economic growth models}

Most models of economic growth assume that the natural resources that are transformed into raw materials are abundant and inexhaustible. Certain authors like Sala-i-Martin (2000) perform their analysis based on three different types of models: steady savings and investment rates; dynamic optimization, and endogenous growth; however, they make no reference to the theme of natural resources. Barro and Sala-i-Martin (1995) incorporate steady savings and investment rates, intertemporal optimization, endogenous growth, and open and closed economies. Likewise, their contribution is the inclusion of human capital; nevertheless, they again leave aside the natural resources and the environment.

The Spanish journal Cuadernos Económicos de ICE devotes its issue No. 58 (1994) to the theory of economic growth; this issue describes the endogenous growth models and addresses the topics of the economic convergence, the role of the financial markets for economic growth, the importance of the public sector, the analysis of the population, the political-economic balance, and economic growth. However, incorporation of the natural resources and pollution continues to be absent from the papers published therein.

Foley and Michl (1999) use the classical approach, i.e., based on the assumptions of Smith (2003) and Ricardo (1987) they build models whose outcomes do not differ significantly from those proposed by Solow (1956) and Ramsey (1928). Particularly, their Ricardian model approaches land as a scarce production factor, which serves as an introduction to the more general issue of economic growth with depletable resources. It also proposes that, as the resources become exhausted, their price will rise until the use of other technologies is rendered profitable. In any case, Foley and Michl deal with issues that are traditionally not addressed in the literature of economic growth.

Solow (1986) criticizes economic growth models for not taking the natural resources into account and considers overlapping generations models as the best option for dealing with these; besides, he establishes that the profits for the future generations should be, at least, equal to those for the present generation, and proposes that the natural capital should at least remain constant. Jouvet et al. (2000) agree with the said author in terms of modeling across overlapping generations, and they suggest that there is an intergenerational altruism that becomes manifest whenever pollution reaches critical levels. They point out that paying little attention to the future generations may result in higher levels of consumption today at the expense of the natural capital of the future.

On the other hand, Howarth and Nogaard (1990) have created a model that encompasses three overlapping generations and emphasize 
Por otro lado, Howarth y Nogaard (1990) crean un modelo de tres generaciones traslapadas y enfatizan la necesidad de que los derechos de propiedad sobre los recursos naturales corresponden a la generación joven, a fin de evitar que las maduras y viejas los agoten. John y Pecchenino (1997) indican que el problema de las externalidades ambientales no solo es intergeneracional, sino internacional; por ello, sugieren la creación de un organismo que integre ambos aspectos, que será responsable de regular el uso de los recursos naturales, y de la emisión de contaminantes.

Otros modelos de crecimiento económico ecológico centran la discusión en la equidad intergeneracional, los mercados incompletos y el altruismo (Doeleman y Sandler, 1998; Krautkraemer y Batina, 1999); estos se fundamentan en el modelo de generaciones traslapadas con diferentes variantes y supuestos. Brock y Taylor (2004) desarrollaron el Modelo Ecológico de Solow (Green Solow Modell que incorpora los elementos contaminación, tecnología y costo de abatimiento de la contaminación; y concluyeron que en el largo plazo el cambio tecnológico ayudará a erradicar la contaminación. Su principal aporte es la integración de la contaminación al modelo de Solow, lo cual originó la Curva Ecológica de Kuznets; es decir, la relación entre el cociente contaminación/producción contra la producción. Dicha curva tiene forma de "U" invertida y muestra que para bajos niveles de producción, un país tenderá a contaminar más; eventualmente, la tasa de contaminación declinará. Así, cuanto mayor sea el crecimiento económico de una nación, menor será la emisión de contaminantes. No obstante, en la investigación se excluye, de forma explíita, el tema de la materia prima virgen y de la reciclada.

La información sobre crecimiento económico ha evolucionado; de tal forma que se han tornado más complicados y realistas, mediante la incorporación de nuevos elementos. A lo largo de la revisión bibliográfica se observa una constante: se aborda una característica determinada (como el capital humano) y se dejan de lado otros factores (el capital natural o la contaminación). La razón es simple: cuanto más variables tiene el modelo, su tratamiento y entendimiento es más complicado. El mismo camino se ha seguido en el presente trabajo, no se considera el cambio tecnológico ni el capital humano, en cambio, se agregan los elementos recursos naturales y contaminación. Los resultados no cambiarían de manera drástica al incorporar la tecnología u otros tipos de capital, pero lo complicarían más. Por ello, en aras de la simplicidad, se restringe al trabajo a capital físico, recursos naturales y contaminación.

\section{El modelo de Solow-Swan}

El modelo de crecimiento económico más estudiado durante años fue el de Harrod-Domar (HD), hasta la creación del Solow-Swan, el cual es más flexible y tiene la virtud de mostrar que la economía puede llegar a un estado estacionario. the need to assign to the younger generation the property rights over the natural resources in order to prevent the depletion of these by the mature and older generations. John and Pecchenino (1997) point out that the issue of environmental externalities is not only intergenerational but also international; for this reason, they suggest the creation of an agency that will integrate both aspects and will be responsible for regulating the use of the natural resources and the emission of pollutants.

Other economic growth models focus their discussion on intergenerational equity, incomplete markets, and the altruism (Doeleman and Sandler, 1998; Krautkraemer and Batina, 1999); these are based on the overlapping generations model, with different variants and assumptions. Brock and Taylor (2004) developed the Green Solow Model, which incorporates the elements of pollution, technology, and the cost of pollution abatement, and they concluded that in the long term the technological change will help eradicate pollution. Their main contribution is the integration of pollution to the Solow model, which gave rise to the the Environmental Kuznets Curve, i.e., the relationship between the pollution-output ratio and production. The said curve has the shape of an inverted "U" and shows that a country with low levels of production will tend to cause more pollution, and that eventually the pollution rate will drop. Thus, the greater the economic growth of a nation, the lower the emission of pollutants. Nevertheless, the research explicitly excludes the topic of virgin and recycled raw materials.

Information on economic growth has evolved, becoming more complicated and realistic as new elements are incorporated. Throughout the bibliographical review a constant feature may be observed: while a specific characteristic (such as the human capital) is addressed, other factors (namely the natural capital or pollution) are left aside. The reason for this is simple: the more variables the model has, the more complex it is to process and understand. This paper has followed same path -it addresses neither the technological change nor the human capital; on the other hand, it adds the elements of the natural resources and pollution. The outcome may not change drastically with the incorporation of technology or other types of capital, but these may render it more complicated. Therefore, for the sake of the simplicity, labor is here restricted to physical capital, natural resources, and pollution.

\section{The Solow-Swan model}

For years the most widely studied economic growth model was that of Harrod-Domar (HD), until the creation of the Solow-Swan model, which is more flexible and has the virtue of showing that the economy can attain a steady state.

In his original work, Solow (1979) puts forth a constant returns to scale production function, or else, a homogeneous production function of degree one. This assumption is fundamental, since most textbooks utilize it to express the dynamics of capital in 
En su trabajo original, Solow (1979) plantea una función de producción con rendimientos constantes a escala, o bien, homogénea de grado uno. El supuesto es fundamental, ya que la mayoría de los libros de texto lo utilizan para expresar la dinámica del capital en términos per cápita. Aunque existen variantes del modelo en los que se incluyen el cambio tecnológico, el capital humano y el capital natural; el análisis no se modifica de manera drástica. Por tanto, este ensayo se refiere a la materia prima y el análisis de la contaminación.

Antes de abordar el modelo de Solow-Swan a través de los pasos de Sala-i-Martin, se asume que la productividad marginal de los factores es positiva, pero decreciente, y que la productividad marginal del capital se aproxima a cero cuando el capital tiende a infinito, y a infinito cuando el capital tiende a cero. Esto satisface las condiciones de nada; lo mismo se aplica al caso del factor trabajo.

Así, la función de producción es:

\section{$Y=F(L, K)$}

Donde:

$Y=$ Producto total de la economía

L= Factor trabajo de la economía

$K=$ Capital utilizado en la economía

Donde se satisface:

$$
\begin{gathered}
\frac{\partial F}{\partial K}>0, \frac{\partial F}{\partial L}>0 ; \frac{\partial^{2} F}{\partial K^{2}}>0, \frac{\partial^{2} F}{\partial L^{2}}>0 \\
\operatorname{Lim}_{K \rightarrow \infty} \frac{\partial F}{\partial K}=0, \operatorname{Lim}_{K \rightarrow 0} \frac{\partial F}{\partial K}=\infty \text { y } \operatorname{Lim} l \rightarrow \infty \frac{\partial F}{\partial L}=0, \operatorname{Lim} m_{l \rightarrow 0} \frac{\partial F}{\partial L}=\infty
\end{gathered}
$$

Dinámica del trabajo. Se considera que la población crece a una tasa constante $n$, y que la oferta de trabajo se contrata inelásticamente y es igual al total de la fuerza de trabajo de la economía.

De modo que:

$$
L(t)=L_{0} e^{n t}
$$

Donde:

$$
L_{0}=\text { Población en el tiempo cero }
$$

De (4) se infiere que:

$$
\ln (L(t))=\ln \left(L_{0}\right)+n t
$$

per capita terms. Although there are variants of the model that include the technological change, the human capital, and the natural capital, the analysis is not drastically modified thereby. Therefore, this paper makes reference to raw materials and to the analysis of pollution.

Before addressing the Solow-Swan model in accordance with the steps described by Sala-i-Martin, we assume the marginal productivity of the factors to be positive, but decreasing; also, we assume the marginal productivity of the capital to approach zero when the capital tends to infinity, and infinity when the capital tends to zero. The conditions of nullity are satisfied thereby. The same applies to the labor factor.

Thus, the production function is:

$$
Y=F(L, K)
$$

Where:

$$
\begin{aligned}
& Y=\text { Total output of the economy } \\
& L=\text { Labor factor of the economy } \\
& K=\text { Capital utilized in the economy }
\end{aligned}
$$

Whereby the following equations are fulfilled:

$$
\begin{gathered}
\frac{\partial F}{\partial K}>0, \frac{\partial F}{\partial L}>0 ; \frac{\partial^{2} F}{\partial K^{2}}>0, \frac{\partial^{2} F}{\partial L^{2}}>0 \\
L m_{K \rightarrow \infty} \frac{\partial F}{\partial K}=0, \operatorname{Lim}{ }_{K \rightarrow 0} \frac{\partial F}{\partial K}=\infty \text { y } \operatorname{Lim} m_{l \rightarrow \infty} \frac{\partial F}{\partial L}=0, \operatorname{Lim} m_{l \rightarrow 0} \frac{\partial F}{\partial L}=\infty
\end{gathered}
$$

Labor dynamics. The population is assumed to grow at a constant rate $n$, and the labor supply is considered to be inflexibly employed and to be equal to the total of the labor force of the economy.

Therefore:

$$
L(t)=L_{0} e^{n t}
$$

Where:

$$
L_{0}=\text { Population at zero time }
$$

From (4) it is inferred that:

$$
\ln (L(t))=\ln \left(L_{0}\right)+n t
$$

Which implies that:

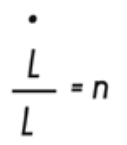

Dynamics of capital. Given that the function of production is homogeneous of degree one: 
Lo que implica que:

$$
\frac{\dot{L}}{L}=n
$$

Dinámica del capital. Dado que la función de producción es homogénea de grado uno:

$$
y=\frac{Y}{L}=\frac{F(L, K)}{L}=f(1, k)=f(k)
$$

Como se sabe, la dinámica del capital es la siguiente:

$$
\dot{K}=s F(L, K)-\delta K
$$

Donde:

$$
\begin{aligned}
& s=\text { Tasa de ahorro de la economía } \\
& \delta=\text { Tasa de depreciación del capital }
\end{aligned}
$$

En términos per cápita:

$$
k=\frac{K}{L}
$$

Por lo tanto:

$$
\ln (k)=\ln (K)-\ln (L)
$$

Derivando con respecto al tiempo:

$$
\frac{\dot{k}}{k}=\frac{\dot{K}}{K}-\frac{\dot{L}}{L}
$$

Despejando y utilizando (6) se obtiene:

$$
\dot{k}=\left(\frac{\dot{K}}{K}-\frac{\dot{L}}{L}\right) \frac{K}{L}=\frac{\dot{K}}{L}-n k=\frac{s F(L, K)-\delta K}{L}-n k=s f(k)-(\delta+n) K
$$

Es decir:

$$
\dot{k}=s f(k)-(\delta+n) k
$$

$$
y=\frac{Y}{L}=\frac{F(L, K)}{L}=f(1, k)=f(k)
$$

As is known, the dynamics of capital are the following:

$$
\dot{K}=s F(L, K)-\delta K
$$

Where:

$$
s=\text { Savings rate of the economy }
$$$$
\delta=\text { Capital depreciation rate }
$$

In per capita terms:

$$
k=\frac{K}{L}
$$

Thus:

$$
\ln (K)=\ln (K)-\ln (L)
$$

Differentiating in relation to time:

$$
\frac{\dot{k}}{k}=\frac{\dot{K}}{K}-\frac{\dot{L}}{L}
$$

By clearing and utilizing $(6)$ the following equation is obtained:

$$
\dot{k}=\left(\frac{\dot{K}}{K}-\frac{\dot{L}}{L}\right) \frac{K}{L}=\frac{\dot{K}}{L}-n k=\frac{s F(L, K)-\delta K}{L}-n k=s f(k)-(\delta+n) K
$$

le.:

$$
\dot{k}=s f(k)-(\delta+n) k
$$

Stability analysis. The model will be stable if the derivative of capital change with respect to capital is negative, i.e., if:

$$
\frac{\partial \dot{k}}{\partial k}=s f^{\prime}(k)-(\delta+n)<0
$$

That is to say, the per capita returns of capital multiplied by the savings rate must be lower than the population growth plus the depreciation rate. This is very likely to occur under the conditions of the proposed production function (11); therefore, the dynamics will correspond to those shown in Figure 1.

Based on the previous formulas, the majority of the papers that utilize this model explain the "golden rule" savings rate, 
Análisis de estabilidad. El modelo será estable si la derivada del cambio en el capital, con respecto al mismo capital es negativa, esto es si:

$$
\frac{\partial \dot{k}}{\partial k}=s f^{\prime}(k)-(\delta+n)<0
$$

Es decir, se requiere que la productividad per capita del capital multiplicado por la tasa de ahorro sea inferior al crecimiento de la población, más la tasa de depreciación. Bajo las condiciones de la función de producción propuesta es muy probable que (11) se cumpla; por lo tanto, la dinámica corresponderá a la que se muestra en la Figura 1. introduce the technological change as well as both the human and natural capital, and observe the new dynamics following the aforementioned changes. This paper omits such discussion and focuses on the possibility that the model may include recycling.

Raw materials and economic growth

The production function is expressed as:

$Y=F(L, K, R M)$

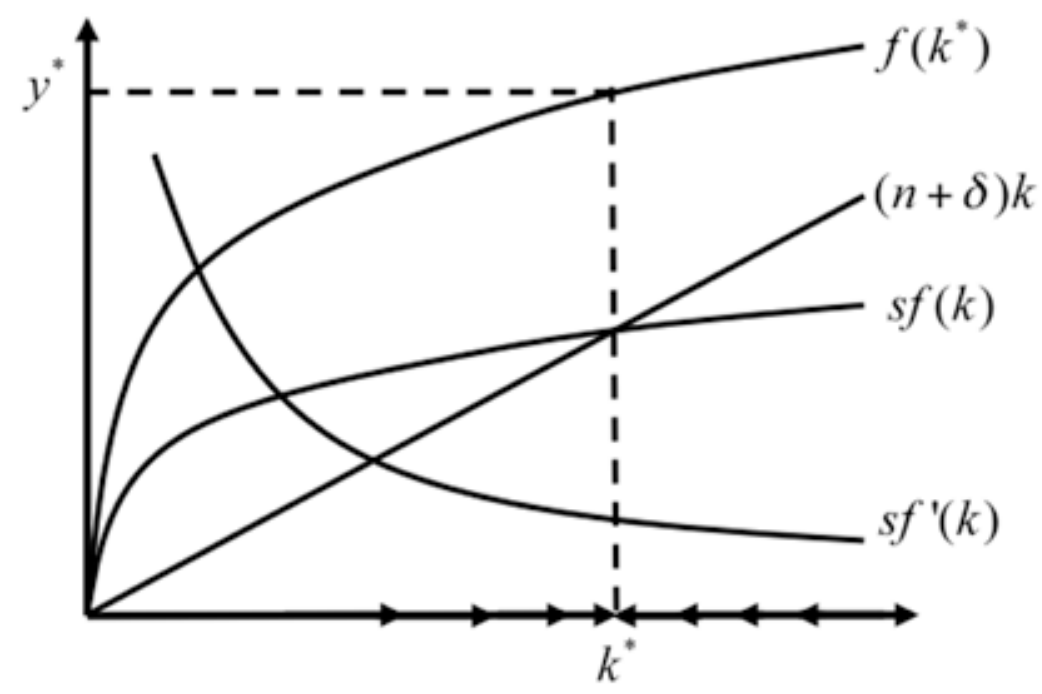

Figura 1. Dinámica del Capital en el modelo de Solow. Figure 1. Dynamics of Capital in the Solow model.

Con base en lo anterior, la mayoría de los artículos que utilizan este modelo explican el ahorro de "la regla de oro", introducen el cambio tecnológico, el capital humano y el natural, y observan la nueva dinámica a partir de los cambios mencionados. En el presente documento se omite tal discusión y se orienta en la posibilidad de que exista reciclaje en el modelo.

La materia prima y el crecimiento económico

La función de producción se plantea como:

$Y=F(L, K, M P)$

Donde:

$Y=$ Producto total

$L=$ Mano de obra de la economía

MP= Materias primas disponibles en la economía
Where:

$Y=$ Total output

$L=$ Labor of the economy

$M P=$ Raw materials available in the economy

The production function is assumed to be HDG- 70 in its three inputs; therefore, it may be expressed in per capita terms as:

$$
y=f(k, r m)
$$

An example of this is the Cobb-Douglas type production function:

$$
y=\frac{Y}{L}=\frac{F(L, K M P)}{L}=\left(\frac{L}{L}\right)\left(\frac{K}{L}\right)\left(\frac{R M}{L}\right)=k^{b} m p^{g}
$$

The raw materials show the following behavior:

$$
R M=M V+M R
$$


Se asume que la función de producción es HDG-10 en sus tres insumos, por tanto, la función se puede expresar en términos per cápita como:

$$
y=f(k, m)
$$

Un ejemplo de lo anterior es la función de producción tipo Cobb-Douglas:

$$
y=\frac{Y}{L}=\frac{F(L, K M P)}{L}=\left(\frac{L}{L}\right)\left(\frac{K}{L}\right)\left(\frac{M P}{L}\right)=k \mathrm{mp}
$$

Las materias primas tienen el siguiente comportamiento:

\section{$M P=M V+M R$}

Donde:

$M V=$ Materia prima virgen

$M R=$ Materia prima reciclada

En términos per cápita:

\section{$m p=m v+m r$}

Si se considera que la mp es constante en el tiempo y que no existe reciclaje (es decir, $m r=0$ ), el problema se reduce al modelo de Solow, donde se puede analizar la dinámica del capital, el estado estacionario, la regla de oro, etcétera.

Para el caso de la función de producción Cobb-Douglas, la función es la siguiente:

\section{$y=A k^{B}$}

Donde:

\section{$A=m p^{Y}$}

Es decir, la materia prima podría asumirse como una constante. Sin embargo, interesa el caso donde la materia prima no es fija, por ello es que se estudia su dinámica:

Dinámica de la Materia Prima. La Materia Prima (MP) se descompone en Materia Prima Virgen (MV) y Materia Prima Reciclada (MR). En una primera aproximación, se considera que no existe reciclaje; es decir, $M R=0$. Después, se analiza el comportamiento de la MP cuando la MR es distinta de cero.

Dinámica de la Materia Prima Virgen. En el primer caso se cumple que $M P=M V$. En el modelo se acepta que la MV crece de manera natural en la economía, pero decrece a medida que se usa en los procesos productivos, de este modo:

$$
m v=(m-d-n) m v \quad(16)
$$

Where:

$M V=$ Virgin raw materials

$M R=$ Recycled raw materials

Expressed in per capita terms:

\section{$r m=v m+r m$}

If $\mathrm{mp}$ is considered to be steady in time and there is no recycling (i.e., $\mathrm{mr}=\mathrm{O}$ ), the problem is reduced to the Solow model, by which the dynamics of capital, the steady state, the golden rule savings rate, etc., can be analyzed.

As for the Cobb-Douglas production function, it is expressed as follows:

\section{$y=A k^{B}$}

Where:

\section{$A=m p^{Y}$}

That is to say, the raw materials may be assumed to be constant. Nevertheless, the case that concerns us is that in which the raw materials are not constant; it is for this reason that we engage in the study of their dynamics:

Dynamics of the Raw Materials. The raw materials (RM) break down into Virgin Raw Materials (VM) and Recycled Raw Materials (RM). In a first approach, recycling is considered to be non-existent; i.e., $R M=0$. Subsequently, the behavior of $R M$ is analyzed when $R M$ is different from zero.

Dynamics of the Virgin Raw Materials. In the first case $R M=M V$. The model accepts that the MV increase naturally in the economy, but decrease as they are used in the productive processes, in the following manner:

$$
M V=A e^{(m-d) t}
$$

Thus:

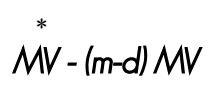

Where:

$$
\begin{aligned}
& m=\text { Growth rate of the natural resources } \\
& d=\text { Rate of decline as a consequence of the use of the } \\
& \text { same in production processes }
\end{aligned}
$$

The analysis of interest is the per capita case; therefore, the dynamics have to be determined in those terms. MP and MV are obtained from equations (14) and (16):

$$
v m=\frac{V M}{L}=\frac{A e^{(m-d) t}}{L_{0} e^{n t}}=\frac{A}{L_{0}} e^{(m-d-n) t}
$$


De modo tal que:

$$
\dot{M V}=(m-d) M V
$$

Donde:

$m=$ Tasa de crecimiento de los recursos naturales

$d=$ Tasa de decrecimiento consecuencia del uso de los mismos en los procesos productivos

El análisis de interés es el caso per cápita; por lo tanto, se tiene que determinar la dinámica en esos términos. La MP y la MV se obtienen de las ecuaciones (14) y (16):

$$
m v=\frac{V M}{L}=\frac{A e^{(m-d) t}}{L_{0} e^{n t}}=\frac{A}{L_{0}} e^{(m-d-n) t}
$$

De donde se infiere que:

$$
\dot{m v}=(m-d-n) m v
$$

De esta ecuación se deduce que la estabilidad de mv se alcanza cuando $m=d+n$; es decir, la tasa de reposición de la naturaleza debe ser igual a la tasa que se utiliza, más la tasa de crecimiento poblacional. Si $m>d+n$, la mp crecerá de forma indefinida. Por el contrario, $m<d+n$, la materia prima per cápita decrecerá exponencialmente. Si $m=d+n$, entonces se trata del modelo de Solow clásico. La Figura 2 ilustra la dinámica de la materia prima.

Si la mp disponible variara, se podrían obtener diferentes funciones de producción (Figura 3).
Whence it is inferred that:

$$
v m=(m-d-n) v m
$$

From this equation it is inferred that stability of $m v$ is attained when $m=d+n$; that is to say, the rate of recovery of nature should be equal to the rate at which it is utilized plus the population growth rate. If $m>d+n$, then $r m$ will grow indefinitely. On the contrary, if $m<d+n$, the per capita raw materials will decrease exponentially. If $m=d+n$, the classical Solow model is being followed. Figure 2 illustrates the dynamics of the raw materials.

If the available mp were to vary, different production functions could be obtained (Figure 3).

In Figure 3 rm'>rm; therefore, the output is higher for the same level of capital; rm"<rm; therefore, the output is lower for the same level of capital. If $r m$ increases, so will the output, and if rm diminishes, the output will decrease as well. In an extreme case, if the natural resources are eventually depleted, the total output will be zero.

Figures 2 and 3 show that it is important to allow the environment to regenerate in order for there to be production in the long term. The risk of carrying out an irrational exploitation is that in the long term there simply will be no more raw materials that can be transformed into goods or services. Hence the importance of producing with an exploitation rate that allows nature to regenerate.

f mp changes, the long-term capital will also change (Figure 4).

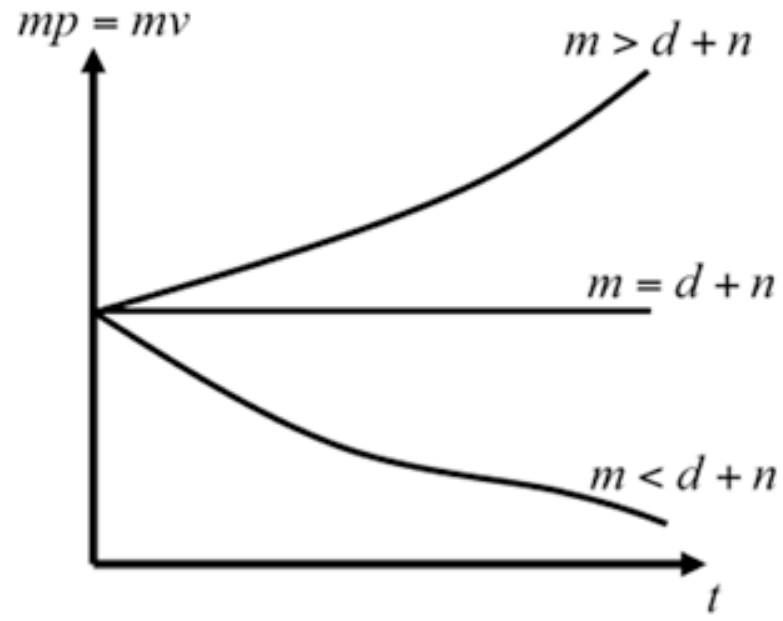

Figura 2. Dinámica de la materia prima virgen en términos per cápita. Figure 2. Dynamics of the raw materials in per capita terms. 


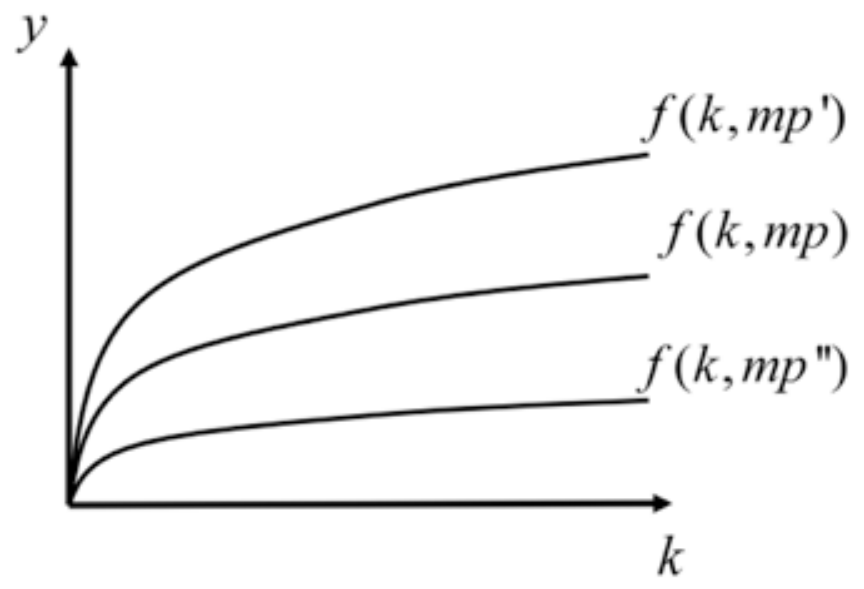

Figura 3. Comportamiento de la producción para diferentes niveles de mp. Figure 3. Production behavior for different mp levels.

En la Figura 3 mp'>mp, por lo que para el mismo nivel de capital la producción es mayor; mp"<mp, por lo que, igualmente, para el mismo nivel de capital el producto es menor. Si la mp crece, el producto también lo hará, si se reduce el producto decrecerá. En el extremo, ante el eventual agotamiento de los recursos naturales, el producto total será cero.

En las figuras 2 y 3 se observa que es importante permitir que el medio ambiente se regenere para producir en el largo plazo. El riesgo de efectuar una explotación irracional es que simplemente no habrá materia prima que pueda ser convertida en bienes o servicios en el largo plazo. De ahí la relevancia de producir con una tasa de explotación que permita a la naturaleza regenerarse.

Si la mp cambia, el capital de largo plazo también lo hará (Figura 4).
Recycling increases the available mp, making it possible to attain a steady-state level of capital such as $k^{* * *}$.

In the presence of recycling the raw materials change to:

Where:

\section{$R M=V M+R M$}

\section{$R M=$ Raw Materials \\ $V M=$ Virgin Raw Materials \\ $R M=$ Recycled Raw Materials}

$R M$ is a percentage of the pollution that is recovered and incorporated in the production process. The analysis of these dynamics is studied subsequently. For the time being, suffice it

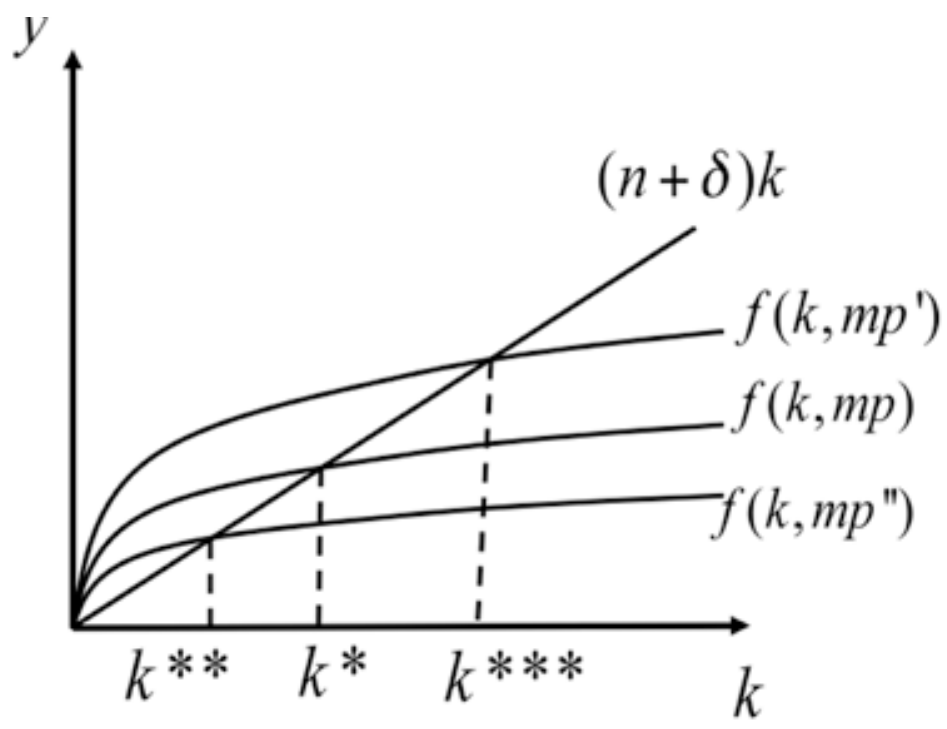

Figura 4. Diferentes niveles de $k^{*}$ para diferentes niveles de mp. Figure 4. Different levels of $k^{*}$ for different levels of $\mathrm{mp}$. 
La presencia del reciclaje incrementa la mp disponible; por ende, se podría alcanzar un nivel de capital en el estado estacionario como $k^{* * * *}$.

\section{Dinámica de la Materia Prima Reciclada}

En presencia de reciclaje la materia prima deviene en:

\section{$M P=M V+M R$}

Donde:

$$
\begin{aligned}
& M P=\text { Materia Prima } \\
& M V=\text { Materia Prima Virgen } \\
& M R=\text { Materia Prima Reciclada }
\end{aligned}
$$

La MR es un porcentaje de la contaminación recuperada e incorporada en el proceso productivo. El análisis de esta dinámica se estudia a continuación. Por ahora basta saber que la contaminación se refiere a desperdicios generados antes, durante los procesos productivos o después del consumo de los mismos; por ejemplo, el ruido producido por las fábricas; así como el humo que generan estas, y los vehículos automotores; además de los desperdicios procedentes de los bienes consumidos (como envolturas).

En todos los casos se asume que la contaminación es resultado de la producción:

\section{$P=G(Y)=u F(L, K, M P)$}

(20)

Es decir, la contaminación (P) es un porcentaje del producto total.

Caracterizada la contaminación, se define la MR como la parte de la materia contaminante $(\alpha)$ rescatada e incorporada en el proceso productivo. De este modo:

$M R=\boldsymbol{\alpha} P=\boldsymbol{\alpha} G(Y)=\boldsymbol{u} \boldsymbol{\alpha} F(L, K, M P) \quad(21)$

En términos per cápita:

$$
m r=a p=\alpha g(y)-u \alpha f(k, m p)
$$

Se incorpora la MR en la MP:

$$
M P=M V+M R
$$

En términos per cápita:

$$
m p=m v+m r
$$

to know that pollution refers to wastes generated before and during the production processes or after the consumption of the output; for example, the noise and the smoke produced by factories and motor vehicles, besides the waste originating in the goods consumed (such as wrappings).

In all cases it is assumed that pollution is a result of production:

$$
P=G(Y)=\text { UF }(L, K, R M)
$$

l.e., pollution $(P)$ is a percentage of the total output.

Once pollution has been characterized, MR is defined as that part of the polluting matter $(\boldsymbol{\alpha})$ which is recovered and incorporated in the production process. Thus:

$$
R M=\alpha P=\alpha G(Y)=v \alpha F(L, K, R M)
$$

In per capita terms:

$$
r m=a p=\alpha g(y)-u \alpha f(k, r m)
$$

$R M$ is incorporated into $R M$ :

In per capita terms:

\section{$R M=V M+R M$}

\section{$r m=v m+r m$}

From equation (18) it is inferred that:

$$
r m=\frac{A_{e}(m-d-n) t_{+} r m}{L_{0}}
$$

This implies that there will be a larger amount of available matter in the economy. Consequently, the level of capital in the steady state will be higher

This implies that there will be a larger amount of available matter in the economy. Consequently, the level of capital in the steady state will be higher.

Analysis of pollution

Pollution has the following dynamics:

$$
P=G(Y)=u f(L, K, R M)
$$

By itself nature absorbs part of the pollution; besides, if there is recycling, the recycled matter ceases to be pollution, so that the change in pollution occurs according to the following equation:

$\dot{P}=u F(L, K, R M)-a P-R M=u F(L, K, R M)-a P-v \alpha F(L, K, R W)(24)$ 
De la ecuación (18) se infiere que:

$$
m p=\frac{A e^{(m-d-n) t}+m r}{L_{0}}
$$

Esto implica que habrá más cantidad de materia disponible en la economía. En consecuencia, el nivel de capital del estado estacionario será mayor.

Análisis de la contaminación

La contaminación tiene la siguiente dinámica:

\section{$P=G(Y)=u F(L, K, M P)$}

(20)

La naturaleza por sí misma absorbe parte de la contaminación; adicionalmente, si existe reciclaje, la materia reciclada deja de ser contaminación, de tal forma que el cambio en esta última se da por:

\section{$\dot{P}=u F(L, K, M P)-a P-M P=u F(L, K, M P)-a P-u \alpha F(L, K, M P)(24)$}

Que deviene en:

$$
\dot{P}=u(1-\alpha) F(L, K, M P)-a P(25)
$$

Donde:

$a=$ Tasa a la que la naturaleza absorbe la contaminación MR= Materia prima reciclada

En términos per cápita:

$$
p=\frac{P}{L}
$$

De donde:

$$
\ln p=\ln P-\ln L
$$

Por tanto:

$$
\frac{\dot{p}}{p}=\frac{\dot{P}}{P}-\frac{\dot{L}}{L}
$$

De donde:

$$
\left.\dot{p}=\mid \frac{\dot{P}}{P}-\frac{\dot{L}}{L}\right) p=\left|\frac{\dot{P}}{P}-n\right| \frac{P}{L}=\frac{\dot{P}}{L}-n p
$$

Que deviene en:

$\dot{p}=\frac{u F(L, K, M P)-a P}{L}-n p=u(1-\alpha) f(k, m p)-(a+n) p(26)$
Which changes into:

$$
\dot{P}=u(1-\alpha) F(L, K, R M)-a P
$$

Where:

$a=$ Rate at which nature absorbs pollution $M R=$ Recycled raw materials

In per capita terms:

$$
p=\frac{P}{L}
$$

Whence:

$$
\ln p=\ln P-\ln L
$$

Therefore

$$
\frac{\dot{p}}{p}=\frac{\dot{P}}{P}-\frac{\dot{L}}{L}
$$

Whence:

$$
\dot{p}=\left|\frac{\dot{P}}{P}-\frac{\dot{L}}{L}\right| p=\left|\frac{\dot{P}}{P}-n\right| \frac{P}{L}=\frac{\dot{P}}{L}-n p
$$

Which changes into:

$$
\dot{p}=\frac{u f(L, K, R M)-a P}{L}-n p=u(1-\alpha) f(k, r m)-(a+n) p(26)
$$

Analysis of stability:

The level of pollution in the long term will be stable if the derivative of the change in pollution in regard to pollution is negative:

$$
\frac{\partial \dot{p}}{\partial p}=-(a+n)<0
$$

Since we assumed by construction that $a>0, n>0$, we conclude that the level of pollution will be stable in the long term (Figure 5).

Dynamics of pollution and capital without recycling

In the absence of recycling ( $r m=0)$, equations 28 and 29 determine the dynamics of the economy:

$$
\dot{k}=s f(k, m v)-(\delta+n) k
$$

$$
\dot{p}=\text { uf }(k, m p)-(a+n) p
$$




\section{Análisis de estabilidad}

El nivel de contaminación en el largo plazo será estable, si la derivada del cambio en la contaminación con respecto a ella misma es negativa:

$$
\frac{\partial \dot{p}}{\partial p}=-(a+n)<0
$$

Dado que se asumió por construcción que $a>0, n>0$, se concluye que el nivel de contaminación será estable en el largo plazo (Figura 5).
The steady state is attained when both equations equal zero (Figure 6):

$$
\dot{k}=s f(k, m v)-(\delta+n) k=0
$$

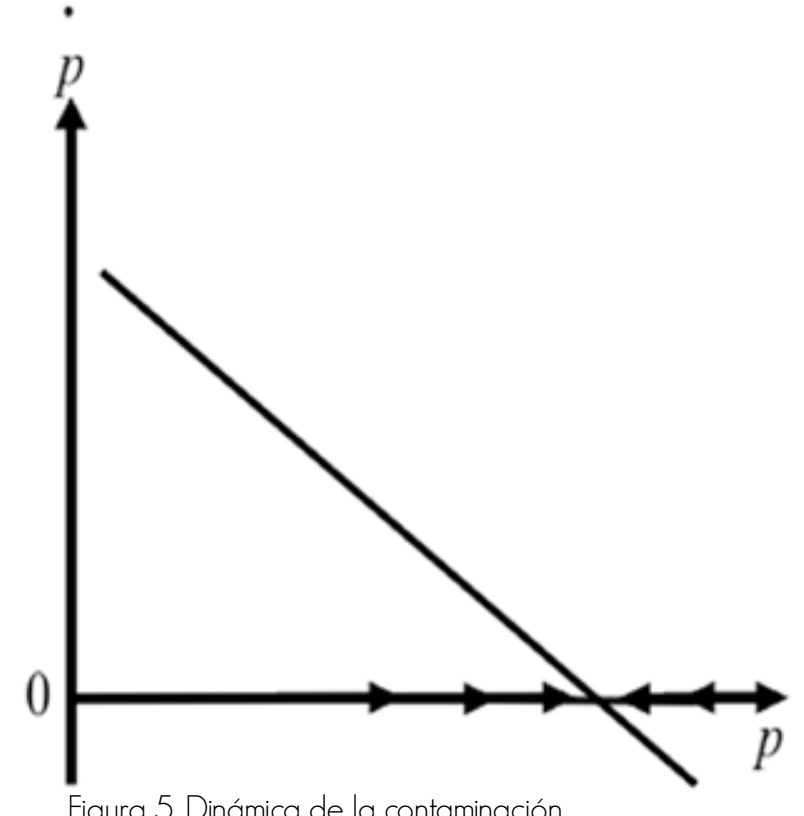

Figura 5. Dinámica de la contaminación

Figure 5. Dynamics of pollution.

Dinámica de la contaminación y el capital sin reciclaje

En ausencia de reciclaje $(m r=0)$, las ecuaciones 28 y 29 determinan la dinámica de la economía:

$$
\begin{aligned}
& \dot{k}=s f(k, m v)-(\delta+n) k \\
& \dot{p}=u f(k, m p)-(a+n) p
\end{aligned}
$$

El estado estacionario se alcanza cuando ambas ecuaciones son iguales a cero (Figura 6):

$$
\begin{aligned}
& \dot{k}=s f(k, m v)-(\delta+n) k=0 \\
& \dot{p}=u f(k, m p)-(a+n) p=0
\end{aligned}
$$

Stability of the system

In order to determine if the system is stable, the characteristic values of the Jacobian of the system of equations must be calculated:

$$
\operatorname{det}\left|\begin{array}{cc}
s f^{\prime}(k)-(\delta+n)-\lambda & 0 \\
u f^{\prime}(k) & -a-n-\lambda
\end{array}\right|=0
$$

The solution to the previous equation is:

$$
\lambda_{1}=-(a+n)<0 ; \lambda_{2}=s f^{\prime}(k)-(\delta+n)<0
$$

We therefore conclude that the system is stable, as ratified by the graphic analysis (Figure 7).

It is not difficult to observe that the characteristic values of the Jacobian of the new system coincide with those of the previous case; therefore, the new system is also determined to be stable. 

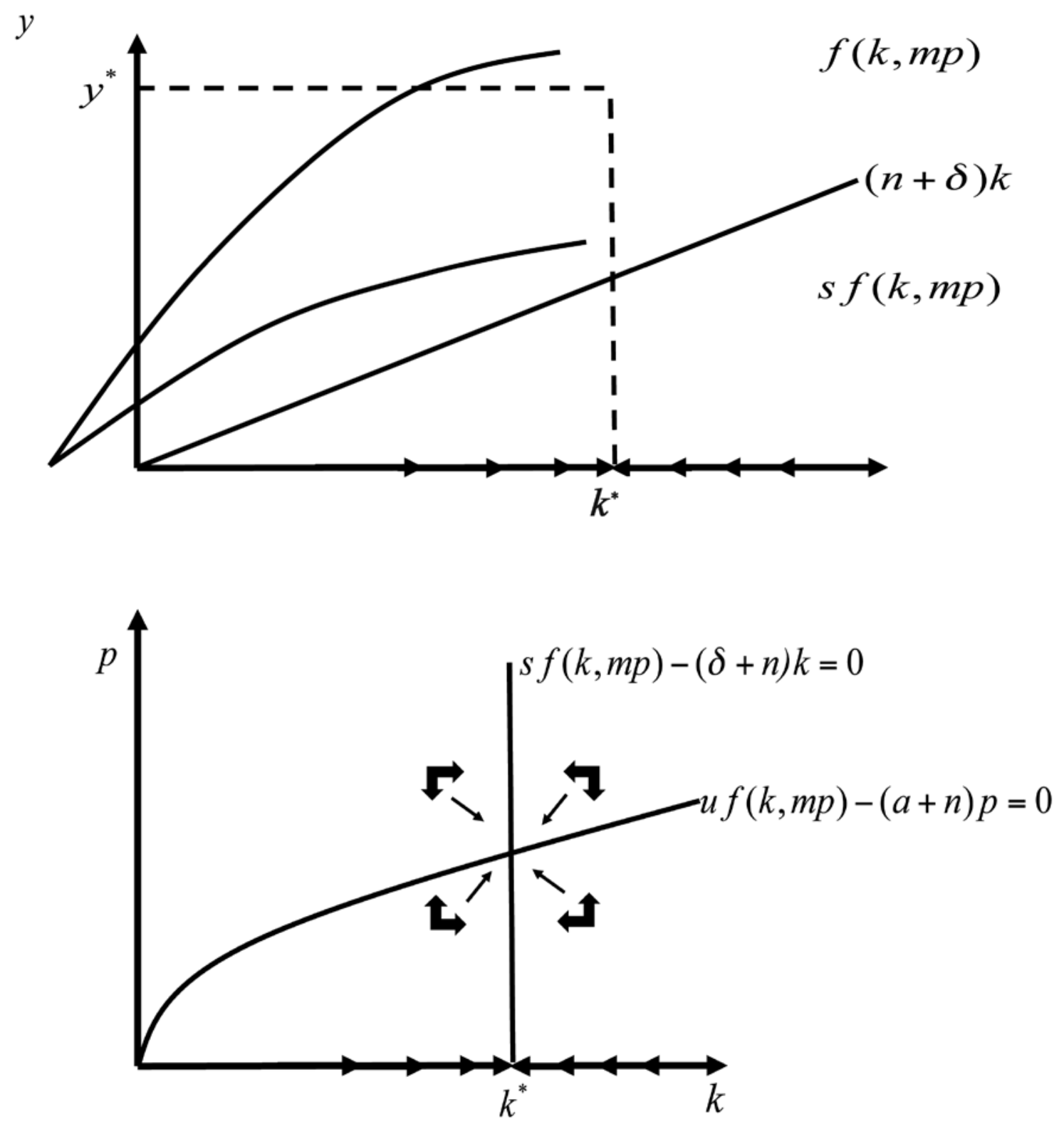

rigura 6. Estado estacionario de la contaminación (p) y el capital (k).

Figure 6. Steady state of pollution (p) and capital ( $k$ ).

\section{Estabilidad del sistema}

Para determinar si el sistema es estable se requiere determinar los valores característicos del Jacobiano, del sistema de ecuaciones

$$
\operatorname{det}\left|\begin{array}{cc}
s^{\prime}(k)-(\delta+n)-\lambda & 0 \\
u f^{\prime}(k) & -a-n-\lambda
\end{array}\right|=0
$$

The graphic analysis shows that recycling results in a higher steady state level of capital $\left(k^{* *}>k^{*}\right)$, as well as in reduced pollution. This indicates that recycling is advisable not only because it abates pollution but also because it results in a higher level of capital and, therefore, in a higher output.

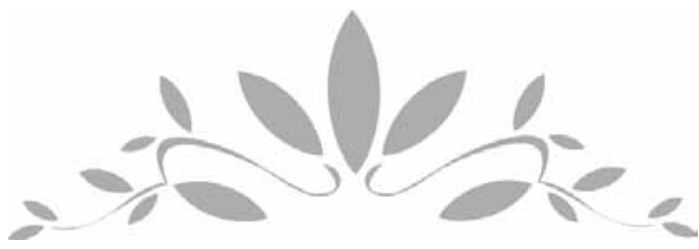


La solución de la ecuación anterior es:

$$
\lambda_{1}=-(a+n)<0 ; \lambda_{2}=s f^{\prime}(k)-(\delta+n)<0
$$

Por lo que se concluye que el sistema es estable como lo ratifica el análisis gráfico (Figura 7).

No es difícil observar que los valores característicos del jacobiano del nuevo sistema coinciden con los del caso previo, por lo cual se determina que este sistema también es estable.

El análisis gráfico permite observar que el reciclaje conduce a la economía a un nivel de capital de estado estacionario mayor que cuando no lo hay $\left(k^{* *}>k^{*}\right)$, mientras que el nivel de contaminación se reduce en presencia de reciclaje. Esto indica
Dynamics of pollution and capital with recycling

The incorporation of recycling slightly modifies the system of differential equations:

$$
\begin{gathered}
\dot{k}=s f(k, m v+m r)-(\delta+n) k=0 \\
\dot{p}=u(1-\alpha) f(k, m p)-(a+n) p=0 \\
\operatorname{det}\left|\begin{array}{cc}
s f^{\prime}(k)-(\delta+n)-\lambda & 0 \\
u(1-\alpha) f^{\prime}(k) & -a-n-\lambda
\end{array}\right|=0
\end{gathered}
$$

Thus, the new steady state is shown in Figure 7.
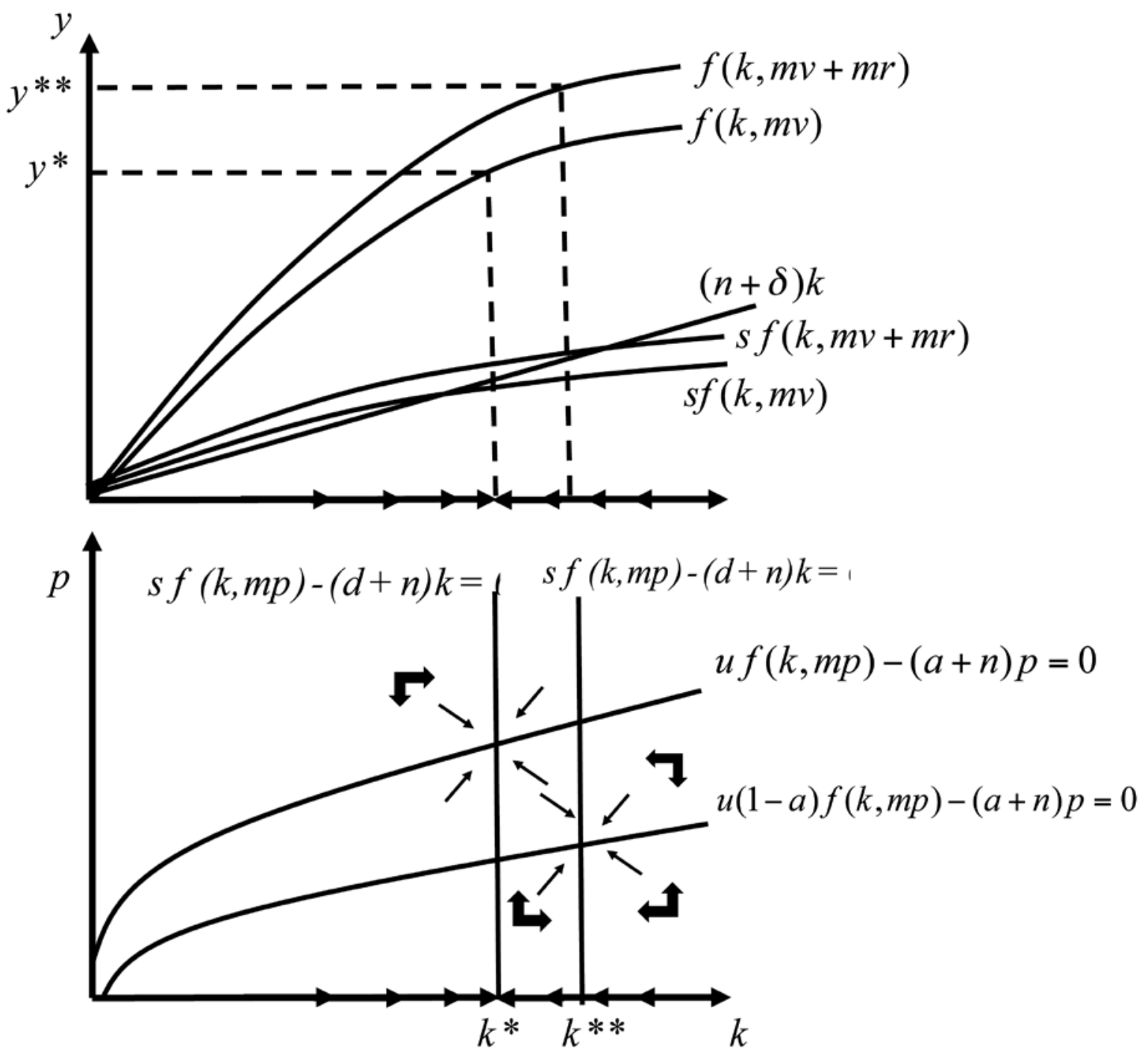

Figura 7. Estado estacionario de la contaminación ( $p$ ) y el capital (k) con reciclaje.

Figure 7. Steady state of pollution $(\mathrm{p})$ and capital $(k)$ with recycling. 
que reciclar conviene no sólo en términos de abatimiento de contaminación, sino también implica un nivel de capital y, por ende, más cantidad de producto.

\section{Dinámica de la contaminación y el capital con reciclaje}

La incorporación del reciclaje modifica ligeramente al sistema de ecuaciones diferenciales:

$$
\begin{gathered}
\dot{k}=s f(k, m v+m r)-(\delta+n) k=0 \\
\dot{p}=u(1-\alpha) f(k, m p)-(a+n) p=0 \\
\operatorname{det}\left|\begin{array}{cc}
s f^{\prime}(k)-(\delta+n)-\lambda & 0 \\
u(1-\alpha) f^{\prime}(k) & -a-n-\lambda
\end{array}\right|=0
\end{gathered}
$$

De esta forma, el nuevo estado estacionario se muestra en la Figura 7.

\section{CONCLUSIONES}

La materia prima se transforma mediante el proceso productivo, el cual también utiliza trabajo y capital para obtener el producto final. Si es estable, corresponde al modelo de Solow-Swan tradicional; si la materia prima se consume con rapidez, se podría llegar al extremo de agotarla y dejar de producir; en cambio si aumenta, sería factible tener mayor crecimiento económico en el largo plazo.

La contaminación surge por el hecho de producir. Todo proceso productivo inevitablemente genera residuos. La dinámica del capital y la contaminación revisados indican que el equilibrio de largo plazo es estable.

La incorporación del reciclaje tiene un impacto doble: reduce la contaminación y provee a la economía de mayor materia prima disponible; por ello, en el equilibrio de largo plazo la contaminación se reduce y los niveles de producción y capital son superiores a los registrados en ausencia de reciclaje. En conclusión, el modelo demuestra que bajo las condiciones típicas del modelo de Solow, a la economía le conviene reciclar sus desperdicios.

\section{REFERENCIAS}

Barro, R. J. and X. Sala-i-Martin. 1995. Economic Growth. Mc Graw-Hill. Cambridge, MA. USA. $539 \mathrm{p}$.

Blanchard, O. J. and S. Fischer. 1989. Lectures on Macroeconomics. The MIT Press. Cambridge, MA. USA. 650 P.

Brock, W. A. and M. Scott Taylor. 2004. "The Green Solow Model". National Bureau of Economic Research. http://www.nber.org/papers/w10557. ( 15 de abril de 2010).

Cuadernos Económicos de ICE. 1994. Ministerio de Comercio y Turismo. Madrid, España. $254 \mathrm{p}$.

\section{CONCLUSIONS}

The raw materials are transformed by means of the production process, which also utilizes labor and capital to obtain the final product. If the raw materials remain stable, then they correlate to the traditional Solow-Swan model. If the raw materials are consumed quickly, they may eventually be depleted, and production may cease; on the other hand, if they increase, a higher economic growth may be feasible in the long term.

Pollution arises as a by-product of production. Every production process inevitably generates waste. The reviewed dynamics of capital and pollution indicate that the long-term equilibrium is stable.

The incorporation of recycling has a two-fold impact: it reduces pollution and provides the economy with more available raw materials; therefore, in the long-term equilibrium pollution is reduced, and the levels of production and capital are higher than those registered in the absence of recycling. In short, the model shows that, under the typical conditions of the Solow model, the recycling of waste is beneficial for the economy.

End of the English version

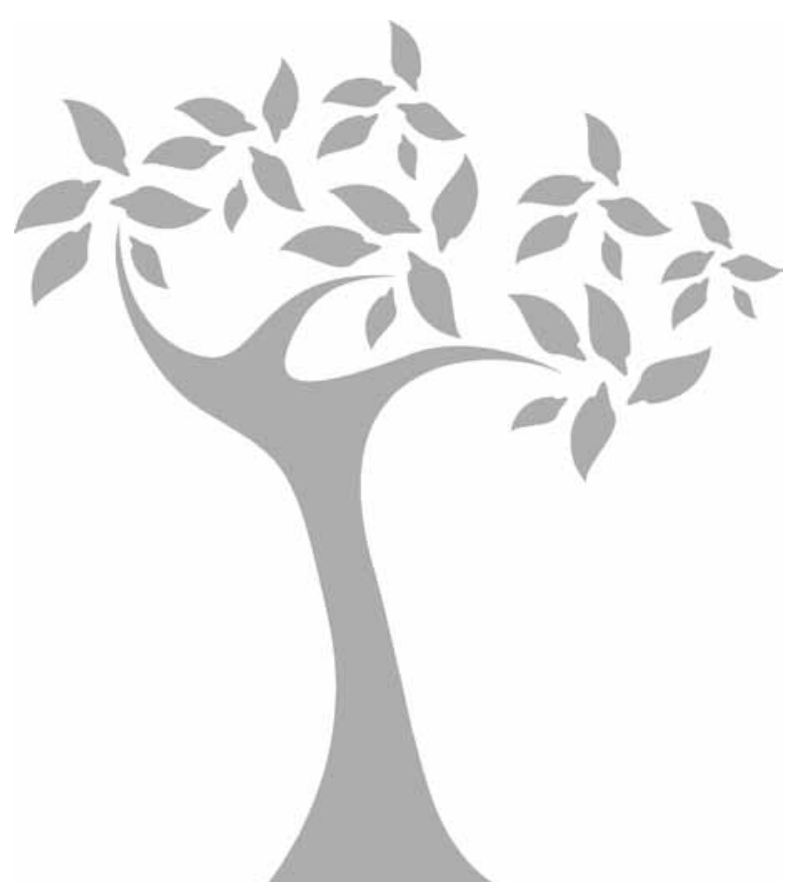


De La Croix, D. and P. Michel. 2002. A Theory of Economic Growth, Dynamics and Policy in Overlapping Generations. Cambridge University Press. Cambridge, UK. 378p.

Diamond, P. 1965. "National Debt in a Neoclassical Growth Model". American Economic Review. 55 (5): 1126- 1154.

Doeleman, J. A. and T. Sandler. 1998. "The Intergenerational Case of Missing Markets and Missing Voters". Land Economics. 74 (1): 1- 15

Domar, E. 1946. "Capital Expansion, rate of growth and employment". Econometrica. 14: 137-147.

Foley, D. and T. R. Michl. 1999. Growth and Distribution. Harvard University Press. Cambridge, MA. USA.355 p.

Harrod, R. F. 1939. "An Essay in Dynamic Theory". Economic Journal. 49: 14-33.

Howarth, R. B. and Richard B. Norgaard. 1990. "Intergenerational Resource Rights, Efficiency, and Social Optimality". Land Economics. 66 (1): 1-11.

John, A. A. and R. A. Pecchenino. 1997. "International and Intergenerational Environmental Externalities". The Scandinavian Journal of Economics. 99 (3):317-387.
Jouvet, P-A., P. Michel and J.P. Vidal. 2000. "Intergenerational Altruism and the Environment". The Scandinavian Journal of Economics. 102 (1): 135-150.

Krautkraemer, J. A. and R. G. Batina. 1999. "On Sustainability and Intergenerational Transfers with a Renewable Resource". Land Economics. 75 (2): 167- 184.

Ramsey, F. 1928. "A Mathematical Theory of Saving". The Economic Journal 38 (152): 543-559.

Ricardo, D. 1987. Principios de Economía Política y Tributación. Fondo de Cultura Económica. México, D.F. México. 332 p.

Sala-i-Martin, X. 2000. Apuntes de Crecimiento Económico. In: Antoni Bosch (Ed). Barcelona, España. $250 \mathrm{p}$

Smith, A. 2003. The Wealth of Nations. Bantam Books. New York, NY USA. 1231 p. Solow, R. M. 1979. "Un modelo de Crecimiento". In: Sen, A. (Ed.): Economía del Crecimiento. Fondo de Cultura Económica. México. México, D. F., México, $525 \mathrm{p}$.

Solow, R. M. 1986. "On the Intergenerational Allocation of Natural Resources". The Scandinavian Journal of Economics. Growth and Distribution: Intergenerational Problems. 88 (1): 141- 149.

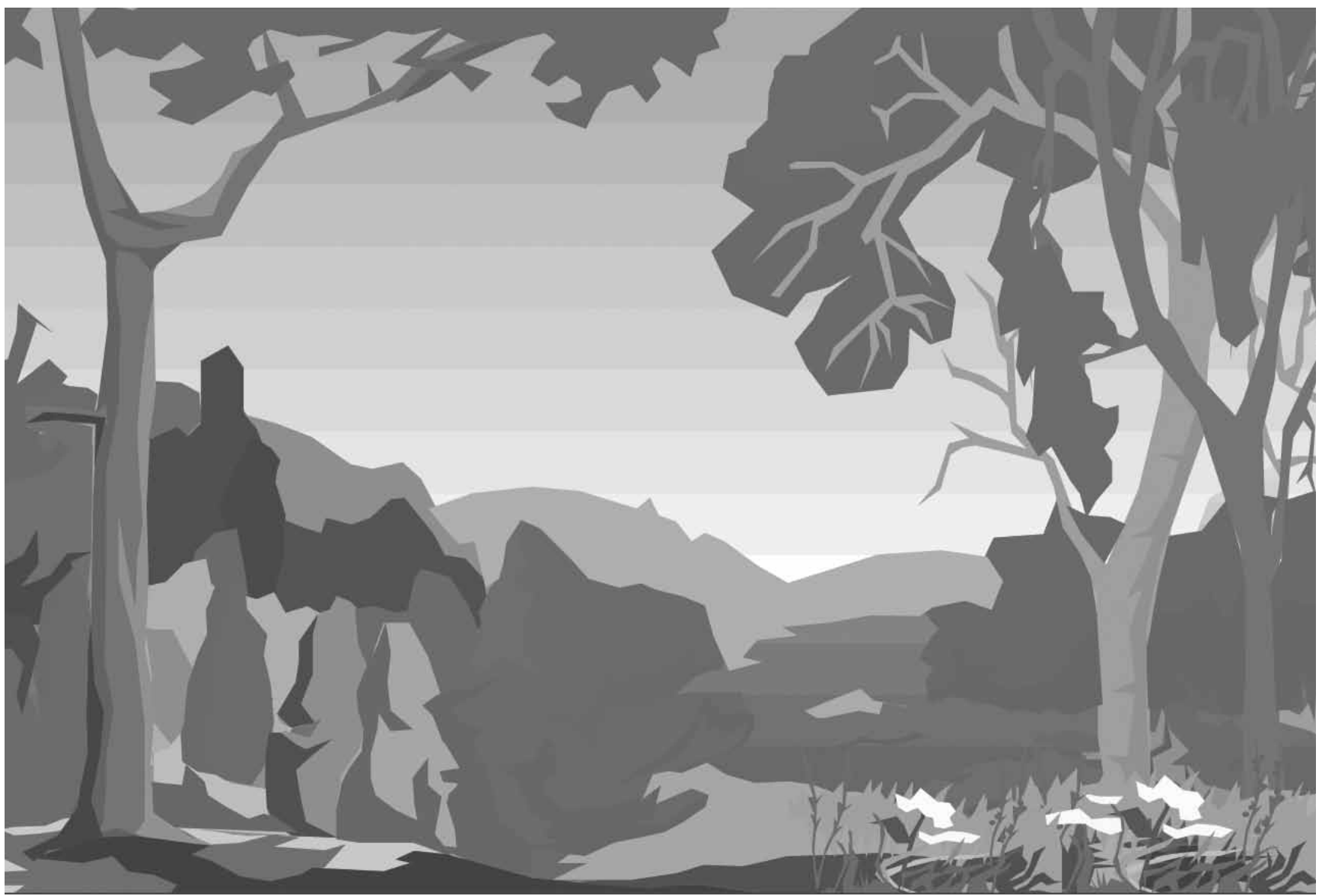




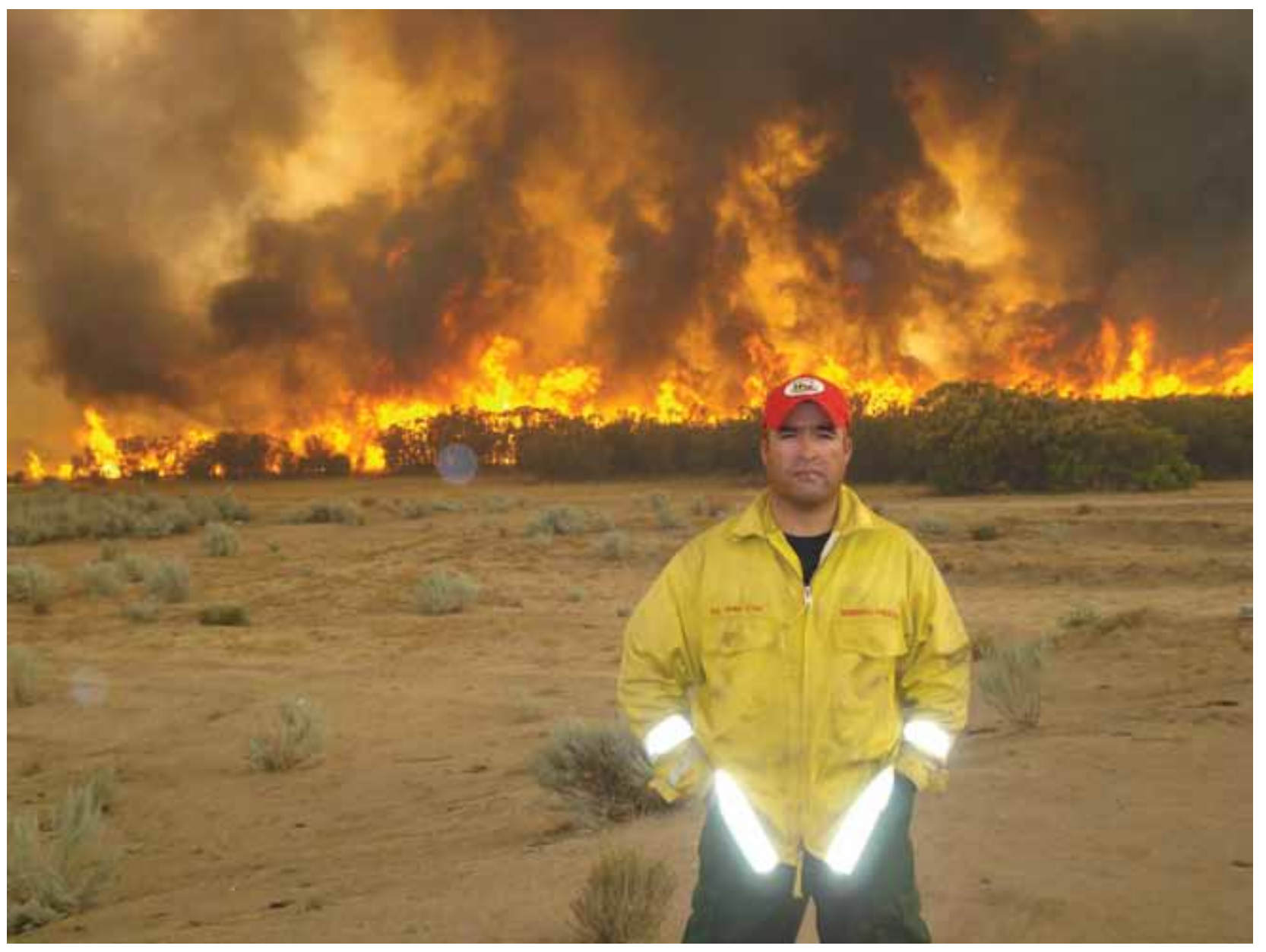

Ing. Juan Ramón Cruz Domínguez, (2009). 